\title{
PERUBAHAN EKSPRESI HEAT SHOCK PROTEIN 70 AKIBAT PAPARAN MEDAN ELEKTROMAGNETIK EXTREMELY LOW FREQUENCY PADA MAKROFAG PERITONEUM MENCIT YANG DIINFEKSI Toxoplasma gondii
}

\author{
Mochammad Arief Taufiqurochman \\ Bagian Histologi Fakultas Kedokteran Universitas Sebelas Maret \\ Jl. Ir Sutami 36A Surakarta \\ Korespondensi: Mochammad Arief Taufiqurochman \\ email: arief_tq@yahoo.com
}

\begin{abstract}
ABSTRAK
Penelitian dilakukan untuk mengetahui efek paparan medan elektromagnetik ELF sebesar $100 \quad \boldsymbol{\mu} \mathbf{T} \quad 8$ jam/ hari selama 2 dan 4 minggu terhadap ekspresi HSP 70 makrofag peritoneum mencit yang diinfeksi dengan Toxoplasma gondii. Jenis penelitian ini adalah Eksperimen Biomedik menggunakan rancangan randomized separate posttest control group designdengan hewan coba mencit strain Balb/c, melalui pengamatan ekspresi HSP 70 , terdiri dari 3 kelompok kontrol dan 4 kelompok perlakuan, tiap kelompok terdiri dari 4 hewan coba. Pengamatan jaringan menggunakan metode imunohistokimia indirek, hasilnya dianalisis menggunakan uji statistik Independent t-test antar kelompok setelah dilakukan uji homogenitas dan normalitas data penelitian $(\alpha=0.05)$. Hasil penelitian menunjukkan bahwa akibat paparanME ELF dengan itensitas $100 \quad \mu T$ selama 2 minggu belum mampu melemahkan atau memutus rantai DNA gen HSP 70 promotor region tetapi menimbulkan stres seluler yang berakibat teraktifasinya HSF 1 melalui konversi menjadi trimer yang akan meregulasi secara cepat sintesis HSP 70. Paparan medan elektromegnetik ME ELF selama 4 minggu dapat melemahkan bahkan memutus rantai DNA hsp 70 promotor region, sehingga sintesis HSP akan terhambat secara signifikan $(p<0.05)$. Terdapat peningkatan secara signifikan ekspresi HSP 70 makrofag peritoneum mencit yang terpapar ME ELF dengan itensitas $100 \quad \mu T$ selama 2 minggu pada kelompok yang terinfeksi toxoplasma gondii dan terjadi penurunan secara signifikan ekspresi HSP 70 pada kelompok terpapar ME ELF selama4 minggu pada kelompok yang terinfeksi Toxoplasma gondi dibandingkan dengan konrol
\end{abstract}

Kata Kunci: Medan Electromagnetik ELF, HSP 70, Makrofag, Toxoplasma gondii.

\section{ABSTRACT}

This research was done to investigate the effect of the ELFelectromagnetic field exposure with the intensity of $100 \mu$ T for 8 hours/day for 2 weeks and 4 weeks on the HSP 70 expression of peritoneal macrophages of the mice infected with Toxoplasmagondi. This research used the biomedical experimental method with randomized post-test control group design. It involved 28 experimental mice of Balb/c strain, and they were divided into four treatment groups and three separate control group. Tissue observation used indirect immunohistochemical technique. Its result was analyzed by using independent- $t$ test following the homogeneity and normality tests on the data of research $(\alpha=0.05)$. The ELF electromagnetic exposure with the intensity of $100 \mu$ T for 2 weeks induces cellular stress which activates HSF 1 will regulate the synthesis of HSP 70 promptly. Conversely, the ELF electromagnetic field exposure for 4 weeks has been able to weaken the chain of DNA in the promoter region of hsp 70 gene. As a result, the synthesis of HSP will significantly be impeded $(p<0.05)$. There is a significant increase in the HSP 70 expresionof peritoneal macrophages of the mice exposed to the ELF electromagnetic field with the intensity of $100 \mu$ T for 2 weeks in the groups which were infected with toxoplasma gondii, but there is a significant decrease in the HSP 70 expresion of peritoneal macrophages of the mice exposed to the ELF electromagnetic field with the intensity of $100 \mu \mathrm{T}$ for 4 weeks in the groups which were infected with Toxoplasma gondii.

Keywords: ELF Electromagnetic field , HSP 70, Macrophage, Toxoplasma gondii. 


\section{PENDAHULUAN}

Dari beberapa penelitian yang pernah dilakukan sebelumnya menunjukkan bahwa baik frekuensi tinggi maupun frekeuensi rendah medan elektromagnetik ternyata dapat menghambat resistensi terhadap infeksi. Penurunan sitoproteksi ditemukan pada embrio ayam setelah mendapat paparan Medan Elektromagnetik Extremely Low Frequency (ELF) dengan intensitas $8 \mu \mathrm{T}$ selama 4 hari berturut-turut (Di Carlo et al, 2002). Paparan medan elektromagnetik ELF dengan intensitas $0,2 \mu \mathrm{T} 4 \mathrm{jam} /$ hari selama 5 hari dapat menimbulkan penurunan jumlah partikel asing yang berhasil difagosit makrofag dan peningkatan konsentrasi ACTH serum sebesar 33,06\% secara signifikan pada hewan Guenia Pig jantan (Zare, 2006). Aktivitas fagositosis merupakan salah satu upaya individu untuk melakukan fungsi proteksi terhadap agen asing yang masuk kedalam tubuh dan proses biodegradasinya. Mengacu pada rekomendasi WHO bahwa intensitas paparan medan magnet $E L F$ di lingkungan ratarata masih berada di bawah nilai ambang batas yang diperkenankan WHO yaitu dibawah 100 mT (SCENIHER, 2006, Johansson, 2009). Namun dari beberapa penelitian epidemiologi maupun eksperimental telah mendukung adanya peningkatan risiko beberapa jenis kanker oleh paparan medan magnet pada intensitas rendah, sehingga masih ada kekhawatiran kemungkinan dampak kesehatan oleh paparan medan magnet pada intensitas rendah $(<100 \mu \mathrm{T})$. oleh karena itu mekanisme respons imun oleh paparan medan magnet ELF pada intensitas lingkungan $100 \mu \mathrm{T}$ masih perlu dikaji lebih lanjut.

Perlu kejelasan efek paparan medan elektromagnetik $E L F$ terhadap penurunan respon imun yang berkitan dengan aktivitas fagositosis makrofag secara patobiologi molekuler. Kenyataan menunjukkan bahwa pemanfaatan peralatan elektronik di rumah tangga dan di lingkungan pekerjaan semakin meningkat hal ini menyebabkan risiko kejadian paparan medan elektromagnetik $E L F$ pada individu menjadi semakin besar dan individu yang mengalami penurunan imunitas berkaitan dengan penurunan aktivitas fagositosis makrofag akan semakin banyak terjadi.

Paparan medan Elektromagnetik ELF akan menginduksi HSP 70 yang bertujuan untuk membantu mempertahankan konforrmasi protein sel selama periode stress. Dilaporkan bahwa paparan medan elektromagnetik ELF menyebabkan peningkatan stress protein $H S P$ 70 dan HSP 110 hanya pada waktu tertentu (Frahm , Mattson , Simco , 2010). Paparan medan magnet $50 \mathrm{~Hz}$, sebesar $2 \mu \mathrm{T}$ yang yang ditimbulkan oleh lilitan Helmholtz selama 10-12 minggu, pada limabelas marmot jantan dewasa menimbulkan penurunan aktivitas sitotoksik $N K$ cells ,dibandingkan dengan kontrol. Data ini menunjukkan bahwa $N K$ Cells sebagai salah satu komponen sistem imun yang mampu membunuh beberapa jenis sel tumor dapat dihambat aktivitasnya oleh paparan medan magnet $50 \mathrm{~Hz}$. Dari uraian tersebut di atas menunjukkan bahwa hasil penelitian eksperimen baik secara invivo mapun invitro sampai saat ini masih belum cukup untuk menjelaskan mekanisme secara mendasar patobiomolekuler paparan medan elktromagnetik ELF $50 \mathrm{~Hz}, 100 \mu \mathrm{T}$ terhadap aktivitas fagositosis makrofag.

Medan elektromegnetik-ELF secara langsung dapat berinteraksi dengan membran sel terutama dengan ion negatif pada dinding bagian dalam kanal protein dan mengubah arah dipole magnet sehingga susunan ion yang semula memiliki formasi acak menjadi searah yang berakibat permiabilitas membran meningkat. Kondisi ini akan berakibat proses fagositosis pada tahap adhesi mikroba oleh makrofag melalui ikatan nonspesifik terutama gaya elektrostatik terganggu dan gangguan ini mengakibatkan tahap ingesti menjadi tidak efektif(Nagura et al, 1993; Walleczek, 1992 ; Yeung et al. 2006).

Paparan medan elektromagnetik ELF dalam waktu singkat merupakan stimulasi stress yang akan menginduksi gene hsp 70 dalam beberapa menit. Dalam kondisi stress, regulasi transkripsi gene hsp 70 dimediasi oleh heat shock transcription factor 1 (HSF1) yang akan mengalami aktivasi secara lengkap melalui konversi struktural monomer menjadi trimer dan mengalami translokasi dalam inti. HSF1 terikat pada heat shock elements (HSEs) dalam gene hsp 70 promotor region dan akan meregulasi secara cepat sintesis HSP sebagai respon dari berbagai stress lingkungan. Dalam kondisi normal ketika gene $h s p 70$ tidak diinduksi untuk transkripsi, maka RNA Polymerase II (RNA P II) menghentikan regio transcription initiation site pada nukleotida ke 20-40. Stimulasi stress akan melepaskan 
pengaruh $R N A P$ II dalam waktu kurang dari 30 menit, dengan demikian akan terjadi peningkatan ekpresi HSP 70 (Karniranta, 2002).

Akan tetapi Specific DNA sequences pada promoter gene $h s p 70$ memberikan respon terhadap medan elektromagnetik . Studi sistem model biokimia menunjukkan bahwa medan elektromagnetik juga dapat berinteraksi langsung dengan elektron DNA. Medan elektromagnetik dengan energi rendah akan menginduksi repons stress, namun peningkatan energi atau pertambahan waktu paparan dapat melemahkan sampai memutus rantai DNA. Kondisi itu dapat menyebabkan penurunan ekspresi HSP 70 (Blank and Godman, 2009).

Akumulasi ion $\mathrm{Ca}$ dalam sitosol dapat berpengaruh sama terhadap elektron DNA khususnya pada gen hsp 70 promotor region yang berakibat pelepasan hambatan RNA P II terhadap transcription ignition side region pada nukleotida ke 20-40tidak dapat optimal, sehingga sisntesis HSP 70 akan terganggu (Frahm et al., 2004) Oleh karenanya ketika terjadi stress seluler berupa peningkatan ROS akibat masuknya mikroba ke dalam sel tidak dapat memicu peningkatan ekspresi HSP 70. Dengan demikian maka proses refolding enzimatis untuk enzim-enzim biodegradasi mikroba antara lain adalah Defensin, Cathepsin G, Lisozim, Laktoferin akan tergangguyang akhirnya akan memperlemah proses biodegradasi enzimatis mikroba.

Masalahnya adalah : apakah paparan medan elektromagnetik ELF sebesar $100 \mu \mathrm{T} 8$ jam/ hari selama 2 minggu dan 4 minggu dapat mengakibatkan perubahan ekspresi HSP 70 pada aktivitas fagositosis makrofag peritoneum mencit yang diinfeksi dengan Toxoplasma gondii ? Dengan demikian penelitian ini bertujuan untuk menjelaskan secara imunopatobiologi pengaruh paparan medan elektromagnetik ELF sebesar 100 $\mu \mathrm{T} 8 \mathrm{jam} /$ hari selama 2 dan 4 minggu terhadap ekspresi HSP 70 pada mencit yang diinfeksi dengan Toxoplasma gondii .Hasil penelitian ini diharapkan dapat sebagai dasar pertimbangan untuk melakukan upaya preventif timbulnya efek samping pada para individu yang mengalami paparan medan elektromegnetik ELF disekitar peralatan listrik pada intensitas $100 \mu \mathrm{T}$.

\section{METODE}

Penelitian ini menggunakan rancangan randomized separate posttest control group design. dengan hewan coba mencit strain $\mathrm{Balb} / \mathrm{c}$ jantan, berumur $10 \mathrm{minggu}$, terdiri dari 4 kelompok perlakuan yang mendapat paparan medan elektromegnetik ELF selama 2 dan 4 minggu dan 3 kelompok kontrol . Setiap kelompok terdiri dari 4 hewan coba. Dua hari sebelum diterminasi setiap hewan coba kelompok perlakuan diinfeksi dengan Toxoplasma gondii dengan dosis $10^{3}$ tachyzoite secara intraperitoneal. Pemeriksaan terhadap ekspresi HSP 70 dalam sitoplasma makrofag peritoneum hewan coba dilakukan menggunakan metode imunohistokimia indirek, hasilnya dianalisis menggunakan uji statistik Independent t-test antar kelompok setelah dilakukan uji homogenitas dan normalitas data penelitian $(\alpha=0.05)$.

\section{HASIL DAN PEMBAHASAN}

Pengambilan data ekspresiHSP70 makrofag peritoneum mencit dilakukan melalui pemeriksaan secara mikroskopis dengan pembesaran $100 \mathrm{x}$, setiap 100 sel di setiap lapangan pandang untuk 5 lapangan pandang dengan kriteria penilaian : Skor 0 bila sitoplasma makrofag berwarna biru, skor 1 bila berwarna kuning kecoklatan dan skor 3 bila berwarna coklat.

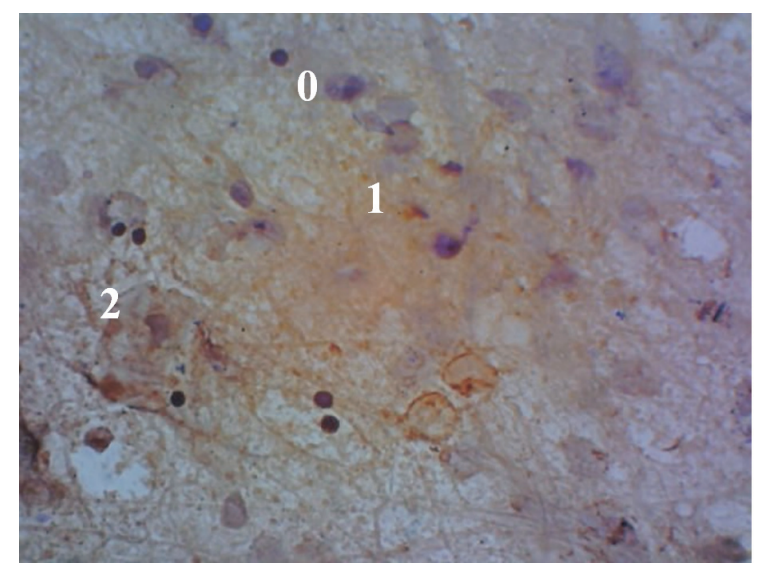

Gambar 5.1 Hasil pengamatan secara $\begin{array}{lll}\text { imunohistokimiaekspresiHSP } & 70 \quad \text { makrofag }\end{array}$ peritoneum sediaan hewan yang mendapat paparan ME selama 2 minggu dan diinfeksi Toxoplasma gondii dengan pembesaran 400x. Angka 1, 2, 3 menunjukkanskorekspresiHSP 70 dalam sitoplasma makrofag (No Sediaan Subjek : 1111) 


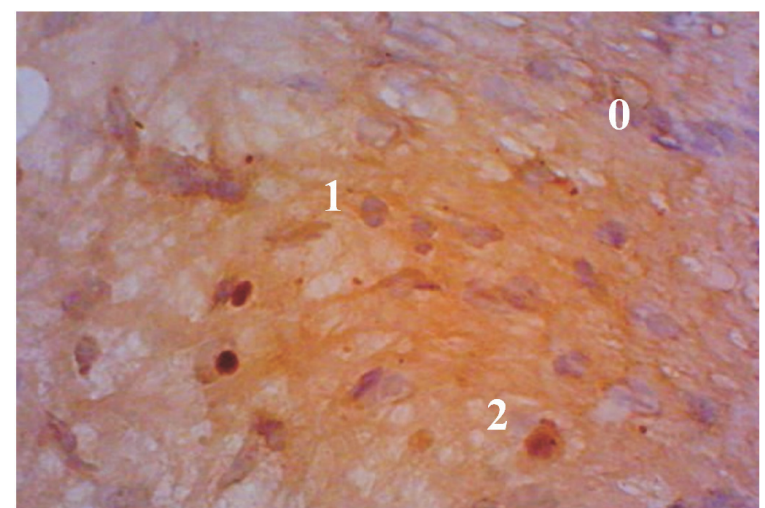

Gambar 5.2 Hasil pengamatan secara imunohistokimia HSP 70 makrofag peritoneum sediaan hewan coba tanpa mendapat paparan ME, diinfeksi Toxoplasma gondii , pembesaran 400x. Angka 1,2, 3 menunjukkan skorekspresi HSP 70 dalam sitoplasma makrofag. (No Sediaan Subjek : 1121)
Setelah dilakukan pengambilan data dan tabulasi, data dianalisis menggunakan uji independent t-tes antara kelompok perlakuan dengan kontrol yang sesuai dengan hasil sebagai berikut;

Tabel 1. Hasil analisis data ekspresi HSP 70 pada kelompok Separate controlmenggunakan independent

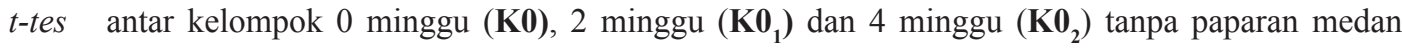
elektromagnetik dan tanpa diinfeksi Toxoplasma gondii. (ME-,To-).

\begin{tabular}{cccccccc}
\hline \multirow{2}{*}{ KELOMPOK } & \multicolumn{9}{c}{ No. Subjek } & \multicolumn{3}{c}{ Uji-t } \\
\cline { 2 - 8 } & 1 & 2 & 3 & 4 & X & $\boldsymbol{p}$ & Sign. \\
\hline K0 (0 mgg) & 197 & 236 & 207 & 226 & 216.50 & & \\
K0 (2 $\mathbf{~ m g g ) ~}$ & 169 & 268 & 215 & 222 & 218.50 & 0.931 & NS \\
K0 $_{\mathbf{2}}$ (4 $\mathbf{~ m g g ) ~}$ & 199 & 229 & 232 & 217 & 221.75 & 0.820 & NS \\
\hline
\end{tabular}

Tidak terdapat perbedaan secara signifikan 2 minggu dan 4 minggu $(\mathrm{p}>0.05)$ eksprei HSP 70 antar kelompok kontrol 0 minggu,

Tabel 2. Hasil pengambilan data ekspresi HSP 70 makrofag peritoneum mencit kelompok kontrol 2 minggu dan 4 minggu $\left(\mathbf{K} \mathbf{0}_{1,2}\right)$ dan kelompok yang mendapat perlakuan 2 minggu $(\mathbf{K 1}, \mathbf{K} 2)$ dan 4 minggu $(\mathbf{K 3}, \mathbf{K 4})$.

\begin{tabular}{|c|c|c|c|c|c|c|c|}
\hline \multirow{2}{*}{$\begin{array}{c}\text { Lama } \\
\text { Perlakuan }\end{array}$} & \multirow[t]{2}{*}{ Kelompok Subjek } & \multicolumn{4}{|c|}{$\begin{array}{c}\text { Ekpresi } H S P 70 \\
\text { No. Subjek }\end{array}$} & \multirow[b]{2}{*}{$X$} & \multirow[b]{2}{*}{$S D$} \\
\hline & & 1 & 2 & 3 & 4 & & \\
\hline \multirow{3}{*}{2 minggu } & K0 $0_{1}: \operatorname{ME~(-)~To~(-)~}$ & 169 & 268 & 215 & 222 & 218.50 & 17.71 \\
\hline & K1 : ME (+) To(+) & 352 & 334 & 602 & 342 & 420,00 & 20,02 \\
\hline & K2 : ME (-) To (+) & 285 & 286 & 308 & 160 & 259,75 & 69,86 \\
\hline \multirow{3}{*}{4 minggu } & $\mathrm{KO}_{2}:$ ME (-) To (-) & 199 & 229 & 232 & 217 & 218,75 & 17,73 \\
\hline & K3 : ME (+) To(+) & 143 & 105 & 189 & 143 & 145,00 & 35,42 \\
\hline & K4 : ME (-) To (+) & 319 & 241 & 252 & 214 & 256,50 & 39,53 \\
\hline
\end{tabular}


Tabel 3 . Hasil Analisis data menggunakan uji independent t-tesekspresi HSP 70 makrofag peritoneum mencit untuk setiap kelompok perlakuan selama 2 minggu $(\mathrm{K} 1, \mathrm{~K} 2)$ dan selama 4 minggu $(\mathrm{K} 3, \mathrm{~K} 4)$ dibandingkan dengan kontrol.

\begin{tabular}{|c|c|c|c|c|c|}
\hline Lama Perlakuan & Kelompok & X0 & $\left(X_{1,2,3,4}\right)$ & $p$ & Sign \\
\hline \multirow{2}{*}{2 minggu } & $\begin{array}{l}\text { K0 }: \text { ME (-) To(-) } \\
\text { K1 : ME (+)To(+) }\end{array}$ & 216.50 & 420,00 & $\mathbf{0 , 0 3 2}$ & $\mathbf{S}$ \\
\hline & K2 : ME (-)To (+) & & 259.75 & 0,334 & NS \\
\hline \multirow{3}{*}{4 minggu } & $\mathrm{KO}_{2}: \mathrm{ME}(-)$ To (-) & 218.75 & & & \\
\hline & K3 : ME $(+)$ To(+) & & 145.00 & $\mathbf{0 , 0 0 7}$ & $\mathbf{S}$ \\
\hline & K4 : ME (-) To (+) & & 256.50 & 0,165 & NS \\
\hline
\end{tabular}

Terdapat peningkatan secara signifikan ekspresi HSP 70 pada kelompok yang mendapat paparan ME ELF selama2 minggu dan diinfeksi dengan Toxoplasma gondii (K1) dibandingkan dengan kontrol $(\mathrm{p}<0,05)$. Terdapat penurunan secara signifikan ekspresi $H S P 70$ pada kelompok yang mendapat paparan ME ELF selama 4 minggu dan diinfeksi dengan Toxoplasma gondii (K3) dibandingkan dengan kontrol $(\mathrm{p}<0,05)$.

Tabel 4. Hasil analisis data menggunakan Uji independent t-test perbedaan ekspresi HSP 70 makrofag peritoneum mencit antar kelompok perlakuan 2 minggu $(\mathrm{K} 1, \mathrm{~K} 2)$ dan 4 minggu $(\mathrm{K} 3, \mathrm{~K} 4)$

\begin{tabular}{ccccc}
\hline \multirow{2}{*}{ Lama Perlakuan } & Kelompok & X & p & Sign \\
\hline \multirow{2}{*}{ 2 minggu } & K1 : ME (+) To(+) & 420,00 & $\mathbf{0 , 0 2 6}$ & S \\
& K2 : ME (-) To (+) & 259,75 & & S \\
\multirow{2}{*}{ 4 minggu } & K3 : ME (+) To(+) & 145.00 & $\mathbf{0 , 0 0 7}$ & \\
\hline
\end{tabular}

Terdapat perbedaan secara signifikan ekspresi HSP 70 antara kelompok K1 dan K2. Paparan ME ELF selama 2 minggu, menimbulkan perbedaan secara signifikan peningkatkan ekspresi HSP 70 makrofag peritoneum dibandingkan dengan yang tidak terpapar ME ELF pada hewan coba yang diinfeksi dengan Toxoplasma gondii $(\mathrm{p}<0.05)$. Terdapat perbedaan secara signifikan ekspresi HSP 70 antara kelompok K3 dan K4. Paparan ME ELF selama 4 minggu, menurunkan secara signifikan ekspresi HSP 70 makrofag peritoneum dibandingkan dengan kelompok yang tidak terpapar ME ELF pada hewan coba yang diinfeksi Toxoplasma gondii $(\mathrm{p}<0,05)$.

Dari hasil analisis data penelitian terdapat peningkatan secara signifikan ekspresi HSP 70pada kelompok yang mendapat perlakuan paparan ME ELF selama 2 minggu dan diinfeksi
Toxoplasma gondii dibandingkan dengan kontrol $(\mathrm{p}<0,05)$. Hal ini menunjukkan bahwapaparan ME ELF selama 2 minggu menyebabkan permiabilitas membrane sel terhadap ion $\mathrm{Ca}$ meningkat dan terjadi akumulasi ion $\mathrm{Ca}$ dalam sitosol namun belum dapat mempengaruhi elektron DNA pada Gen HSP 70 promotor region. Sementara itu Infeksi Toxoplasma gondii memicuaktifitas fagositosismakrofagyang menimbulkan Respiratory Brust dan akan mengaktifkan secara lengkap $H S F-1$ monomer menjadi trimer yang menyebabkan lepasnya hambatan RNA Polymerase II terhadap Trancription initiation site region sehingga produksi $H S P 70$ meningkat secara signifikan (Karniranta, 2002).

Perlakuan dengan infeksi Toxoplasma gondii tanpa paparan medan elektromagnet $E L F$ menyebabkan peningkatan tidak signifikan 
ekspresi HSP 70 dibandingkan dengan kontrol $(p>0,05)$. Hal ini bisa terjadi karena dengan tidak terjadinya akumulasi ion $\mathrm{Ca}$ dalam sitosol akibat tidak adanya paparan ME ELF, maka pelepasan hambatan RNA Polymerase II terhadap Trancription initiation site region tidak maksimal sehingga masih terjadi sintesis $H S P 70$ namun peningkatan ekspresinya tidak signifikan.

Perlakuan dengan paparan medan elektromagnet ELF selama 4 minggu dengan infeksi Toxoplasma gondii, menyebabkan penurunan Ekspresi HSP 70 secara signifikan dibandingkan dengan kontrol $(p<0,05)$. Hal ini dapat terjadi karena akumulasi ion Ca akibat paparan ME ELF selama 4 minggu dapat melemahkan atau memutus rantai DNA Gen HSP 70 promotor region. Akibatnya pelepasan hambatan RNAP II terhadap transcription ignition site region pada nukleotida ke 2040 tidak optimal sehingga sintesis HSP 70 akan terganggu, oleh karena itu ketika terjadi stress seluler berupa peningkatan ROS akibat masuknya Toxoplasma gondii ke dalam sel tidak dapat memicu peningkatan ekspresi HSP 70. Dengan demikian maka proses refolding enzimatis untuk enzim-enzim biodegradasi mikroba antara lain adalah Defensin, Catepsin G, Lisozim dan Lactoferin akan terganggu yang akhirnya akan memperlemah proses biodegradasi enzimatis.(Albar, 2006 dan Li, Srivastava, 2004)

Perlakuan dengan infeksi Toxoplasma gondii, tanpa paparan medan elektromagnet ELF tidak terjadi peningkatan secara signifikan ekspresi HSP $70(\mathrm{p}<0,05)$. Hal ini bisa terjadi karena dengan adanya infeksi Toxoplasma gondii tanpa adanya paparan medan elektromagnetik $E L F$ dapat menimbulkan stress oksidatif namun belum cukup untuk meregulasi HSF 1 monomer menjadi trimer sehingga pelepasan hambatan RNAP II terhadap Transcription initiation site region tidak optimal sehingga terjadi sintesis HSP 70 namun tidak secara optimal.

Tidak terdapat perbedaan secara signifikan ekspresi HSP 70 antara kelompok yang dipapar dan tidak dipapar medan elektromagnetik ELF selama 2 minggu yang pada kedua kelompok diinfeksi Toxoplasma gondii $(\mathrm{p}>0,05)$. Hal ini bisa terjadi karena paparan medan elektromagnetik ELF selama 2 minggu menyebabkan permiabilitas membrane sel terhadap ion $\mathrm{Ca}$ meningkat dan terjadi akumulasi ion $\mathrm{Ca}$ dalam sitosol namun belum dapat mempengaruhi elektron DNA pada Gen HSP 70 promotor region. Sementara itu Infeksi Toxoplasma gondii memicuaktifitas fagositosismakrofagyang menimbulkan Respiratory Brust dan akan mengaktifkan secara lengkap $H S F-1$ monomer menjadi trimer yang menyebabkan lepasnya hambatan RNA Polymerase II terhadap Trancription initiation site region sehingga produksi $H S P 70$ meningkat secara bersamaan baik pada kelompok terpapar maupun yang tidak terpapar medan elektromagnetik ELF sehingga ekspresi HSP 70 pada kedua kelompok tidak berbeda secara signifikan.

Terdapat perbedaan secara signifikan ekspresi $H S P 70$ antara kelompok yang dipapar dan tidak dipapar medan elektromagnetik ELF selama 4 minggu yang pada kedua kelompok diinfeksi Toxoplasma gondii $(\mathrm{p}<0,05)$. Pada kelompok yang dipapar medan elektromagnetik $E L F$, ekspresi HSP 70 lebih rendah daripada kelompok yang tidak dipapar. Hal ini dapat terjadi karena akumulasi ion $\mathrm{Ca}$ akibat paparan ME ELF selama 4 minggu dapat melemahkan atau memutus rantai DNA Gen HSP 70 promotor region. Akibatnya pelepasan hambatan RNAP II terhadap transcription ignition site region pada nukleotida ke 20-40 tidak optimal atau tidak terjadi sehingga sintesis HSP 70 akan terganggu dan ekspresinya akan menurun (Blank and Godman, 2009)

Kerja HSP lebih banyak di dalam sel, seperti membentuk pelipatan protein tiga demensi, menyiapkan protein yang akan dibuang, dan terikat pada rantai peptida membentuk rangkaian protein. Rangkaian protein ini merupakan kumpulan peptida normal pada semua sel yang sehat.HSP 70 juga berperan untuk menyingkirkan protein yang abnormal dari dalam sel dan berfungsi untuk mempresentasikan peptida ke permukaan sel sebagai antigen dalam membantu sistem imun untuk mengenal sel yang sakit (Li Z, Srivastava , 2004).

Berkaitan dengan fungsi HSP 70 sebagai “chaperone"maka penurunan sintesis HSP 70 akan berakibat menurunnya penyiapan enzimenzim lysosom melalui proses refoldingenzym, sehingga akan berdampak terhadap melemahnya proses biodegradasi bakteri secra enzimatis dalam Lysosom. (Guzhova and Margulis, 2006). HSP 70 yang terikat pada protein baru akan mempertahankan protein dalam keadaan 
tidak terlipat untuk membantu transport protein tersebut melalui membrane ke dalam endoplasmik retikulum atau mitokondria. (Abbas et al, 2009; Albar , 2006).

Dengan demikian maka penurunan ekspresi HSP 70 pada kondisi stress selular akibat paparan ME ELF selama 4 minggu akan berdampak melemahnya sistem imun tubuh di dalam menghadapi infeksi akbat melemahnya pengenalan sel yang sakit oleh sistem imun, melemahnya tahap adhesi fagositosis, terganggunya sintesis enzim lisosom yang diperlukan untuk biodegradasi secara enzimatis dan terganggunya proses transport protein melalui dinding sel.

\section{SIMPULAN}

Berdasakan hasil analisis data dan pembahasan dalampenelitian ini maka disimpulkan bahwa paparan Medan Elektromagnetik ELF 100 $\mu \mathrm{T}$ selama 2 minggu pada kelompok hewan coba yang diinfeksi dengan Toxoplasma gondii dapat meningkatkan secara signifikan ekspresi HSP 70 makrofag peritoneum

Paparan Medan Elektromagnetik ELF 100 $\mu \mathrm{T}$ selama 4 minggu pada kelompok hewan coba yang diinfeksi Toxoplasma gondii menyebabkan penurunan secara signifikan ekspresi HSP 70 makrofag peritoneum.

\section{SARAN}

Perlu diupayakan tindakan protektif terhadap timbulnya efek samping pada individu yang mengalami paparan medan elektromagnetik $E L F$ di sekitar peralatan atau arus listrik dengan intensitas $\geq 100 \mu \mathrm{T}$.

Perlu dilakukan penelitian lebih lanjut untuk mengetahui efek paparan medan elektromagnetik $E L F 100 \mu \mathrm{T}$ terhadap parameter imunokompeten yang lain untuk memperkuat bukti efek paparan terhadap penurunan sistem imunitas tubuh.

\section{DAFTAR PUSTAKA}

Abbas A.K. Lichtman A.H., Pober J.S. 2009 . Cellular and Molecular Immunology. $\quad 4^{\text {th }}$. Ed. Philadelphia, W.B.Saunders Co. pp. 253-351

Ahlbom A. 2001. Neurodegenerative Diseases, Suicide and Depressive Syntoms in Relation to
EMF.Bioelectromagnetics Supplement, Stockolm, Sweden, 5:132-143.

Ajioka JW. et al. 2001. The Toxoplasma gondii Life Cycle. Expert Rev. Mol. Med.:1-19 .

Akan Z, Aksu B, Tulunay A, Bilsel S, Inhan-Garip A. 2010.Electromagnetic field and public health: extremely low frequency (ELF). Bioelectromagnetics. 31(8):603-612.

Albar Z., 2006. Heat Shock Protein. http://www. kalbe.co.id/files/cdk//16 Heat Shock 9.pdf $/ 12 / 11 / 2010$

Anies, 2003. Pengendalian Dampak Kesehatan Akibat Radiasi Medan Elektromagnetik. Jurnal MMI : $38 ; 4$.

Ayse G. Canseven ${ }^{1}$, Seyhan N., MirshahidiS. and ImirT. 2006. Suppression of Natural Killer Cell Activity on Candida Stellatoidea by a $50 \mathrm{~Hz}$ Magnetic Field Informa Health Care , 25:2 pp. 79-85

Blank M and Godman R. 2009. Electromagnetic fields stress living cells. Pathophys., 16:(2-3), pp 71-8. References and further reading may be available for this article. To view references and further reading you must purchase this article.

Brooks GF, Butel JS., Morse S.A., 2004. Jawetz, Melnick, \& Adelberg's Medical Microbiology, 2th ed. The Mc. Graw-Hill Co. Inc. pp. 125-126

Di Carlo A, White A., Guo F.,Garrett P. and Litovitz T., 2002. Chronic electromagnetic field exposure decreases HSP70 levels and lowers cytoprotection.J.of Biochem. 84:3, pp. 447454.

Ennanue E.R and Cerotini J.C., 2003. Immunogenicity of Antigen Bond to the Plasma Membrane of Macrophage .J.Exp.Med $132: 711$.

Erwin D (2012).Heat ShocProtein70. http://www. scribd.com/doc/91179465/Heat-ShockProtein.scribd (27 Maret 2015)

Frahm J, Lantow M, Lupke M, Weiss D.G, Simko M.2004. Extremely low frequency electromagnetic fields as effectors of cellular responses in vitro: Possible immune cell activation.J Cell Biochem.:99 : 167: 177.

Mattson M.O, Simco M.2010. Exposure to ELF magnetic fields modulate redox Related protein expression in mouse macrophages . Toxicol Lett.pp.330-336 .

Goraca A, Ciejka E., Piechota A. 2010. Effects of extremely low frequency magnetic field on the parameters of oxidative stress in heart. $J$ Physiol Pharmacol. 61(3): 38. 
Guzhova I and Margulis B, 2006. Hsp70 Chaperone as a Survival Factor in Cell Pathology. St. Petersburg, Russia, Elsevier Inc. p. 108

Hiswani M. 1996. Toxoplasmosis Penyakit Zoonosis yang perlu diwaspadai oleh Ibu Hamil. http://library.usu.ac.id/download/fkm/fkmhiswani5.pdf. 3 Januari 2014

Johansson O. 2009. Disturbance of the immune system by electromagnetic fields A potentially underlying cause for cellular damage and tissue repair reduction which could lead to disease and impairment. PATPHY. 621:21. pp. 9-18.

Karnovsky M.L. 2002. Matabolic Basic of Phagocytic Activity . Physiol. Rev. 42:143. p.104.

Kim Y., Conover D.L, Lots W.G. Cleary .S.F. 1998. Electric Field Induced Change in Agonist Stimulated Calcium Flux oh Human HL60 Leukemia Cells. Bioel ectromagnetic. 19(6): 336-376.

Karniranta P, and Sistonen L. 2002. Roles of the heat shock transcription factors in regulation of the heat shock response and beyond. FASEB $J .15,1118-31$.

Kresno S.B. 2001. Imunologi: Diagnosis dan Prosedur Laboratorium . $4^{\text {th }}$ ed. FKUI, Jakarta. pp. 102-111

KuntoroH.2009. Dasar Filosofis Metodologi Penelitian. Surabaya. Pustaka Melati. Hal 113-146; 165-188.

Lestari C.D.2010. Lisosom. http://senyawakimia. blogspot.com/2010/02/1isosom.html $(12 / 1 / 2012)$

Li Z, Srivastava P. 2004. "Heat-shock proteins". Current protocols in immunology / edited by John E. Coligan ... [et al.]Appendix 1: doi:10.1002/0471142735.ima01ts58. PMID 18432918.

Luttman W, Bratke K, Kupper M, Myertek D. 2006. Phagocytosis Assays in Immunology. Amsterdam pp. 172-180

Marino A.A. 2004. Power Frequency Electric Filed Induces Biological Changes in Successive Generation of Mice . Experimentia, 36 : 309-311.

Nagura H,Asai Y, Katsumata Y, Kojima K. 1993. Role of Electric Surface Charge of Cell Membrane in Phagocytosis. J Cell Biochem. 93:1. p 83-92.

Narita , Kashara T, 1997. Induction of Apoptosis Cells Death in Human Leukemic Cell line, HL-60 by ELF Electric magnetic Fileds : analysis of the possible mechanism in vitro. In vivo.
11(4): 329-335.

Pockley AG, 2002. Heat Shock Protein, Inflamation and Cardiovascular Desease, Circulation 105: $1012-1017$

Rantam FA, 2003. Metode Imunologi, Airlangga University Press, Surabaya.

Samaj J, Read N.D, Volkmann D, Menzel D, Baluska F. 2005. The endocytic network in plants". Trends Cell Biol.15 (8): 425-433.

Scanalios JG 1997. Oxidatif Stress and the Moleculler Biology of Antioxidant Defenses. Cold Spring Harbor Laboratory Press. pp 343351.

SCENIHR . 2006. Preliminary Opinion on Possible effects of Electromagnetic Fields (EMF) on Human Health. 13.

Sen CK . 1995. Oxidants and Antioxidants in Exercise. J.Appl. Physiol. 79. 675.

Shen B, 1007. Increased Resistance to Oxidative Stress in Tran sgenic plants by Targeting Manitol biosynthesis to chloroplasts. Plants Physiol. 113,1177

Srivastava P. 2006. Heat Shock Protein. Researcher from Wikipedia, http://en.wikipwedia.org/w/ index.php. 29 juli 2010

Steel R.G.D and Torrie J.H. 1991. Principles and Procedures of Statistic . 3th ed. Mc GrawHill, New York.

Subowo. 2009. Imunobiologi . ed.2. Jakarta, CV Sagung Seto. hal. 159-61.

Sudarti, Cahyana N.W, Mahmudsyah S. 2006. The Influence of Extremely Low Frequency (ELF) Magnetic Fileds Induction to the Production of IFN-g on Balb/C Mice. Folia Medica Indonesiana . 42 : (2) pp. 82-88

2007. Pengaruh Paparan Medan Magnet ELF dengan Intensitas 20-32 mT terhadap Modulasi Imunitas pada Mencit Balb/C. Disertasi. Kedokteran Unair Surabaya/ gdlhub-gdl-5189

Sudiana I.K. 2005. Teknologi Ilmu Jaringan dan Imunohistokimia. Sagung Seto, Jakarta.

Szmigielski L, Yakovlev AG, 2006. Granulopoietic reaction in infected rabbits exposed to an $E M F$. St. Petersburg, Russia . Elsevier Inc.

Tjun KE,2014.Radikal Bebas dan Reactive Oxygen Species.http://tipscarahidupsehat.com/ radikal-bebas-dan-reactive-oxygenspecies/12 Februari 2015

Walleczek J. 1992. Electromegnetic Filed Effect on Cells of the ImmunSystem the role 
of Calcium Signaling. FASEB J. Oct. 6(13):3177-3185.

Wang R, Joseph T, Muhlenkamp P, Rajiv J.C. 2006. Exogenous heat shock protein 70 binds macrophage lipid raft microdomain and stimulates phagocytosis, processing, and MHC-II presentation of antigens. Blood, Vol. 107, No. 4, pp. 1636-1642.

WHO. 1998 Extremely Low Frequency (ELF) Fields. Environmental Health Criteria . Geneva p.35.

2001. Electromagnetic fields and public health. Electromagnetic Hypersensitivity. WHO Fact sheet No.296. Geneva: World Health Organization; pp.1-2

Yeung T . Terebiznik M, ${ }^{2}$ Liming Y, ${ }^{1}$ Silvius, $Y^{4}$. 2006. Receptor Activation Alters Inner Surface Potential During Phagocytosis .Science : 313: 5785, pp. 347 - 351 .

Zare S.H., Hayatgeibi S., Alivandi, A.G., Ebadi. 2006. Effects Of $50 \mathrm{~Hz}$ Magnetic Field On Some Factors of The Immune System In Male Guinea Pigs. The Journal of Medical Technology. 3 : 1. pp. 2-6 